\title{
Ampicillin in the treatment of Haemophilus influenzae infections of the respiratory tract
}

\author{
J. ROBERT MAY AND DOREEN M. DELVES \\ From the Institute of Diseases of the Chest, Brompton, London, S.W.3
}

The role of Haemophilus influenzae as the most important pathogenic bacterium in chronic bronchitis and bronchiectasis is now widely accepted. This organism is sensitive to a number of antibiotics, and its temporary suppression in the respiratory tract usually presents no great difficulty. Unfortunately, however, infections caused by it show a strong tendency to relapse when chemotherapy is stopped, and for this reason antibiotics are often administered continuously for long periods, especially during the winter months, to patients who are particularly liable to infection. The antibiotic most commonly used for long-term chemotherapy is tetracycline, and many patients derive striking benefit from it. As a rule, however, this benefit lasts for little longer than the duration of the therapy, even if this is given for many months (May, 1958).

A possible alternative to tetracycline appeared with the advent of ampicillin (alpha-amino benzyl penicillin, Penbritin). This is a derivative of 6aminopenicillanic acid ; it differs from other penicillins in that it is active against a wide range of Gram-negative bacteria in addition to the usual Gram-positive ones (Rolinson and Stevens, 1961). $H$. influenzae was reported by Rolinson and Stevens and by Stewart, Coles, Nixon, and Holt (1961) to be slightly more sensitive to ampicillin than to penicillin $G$, and the former workers also indicated that ampicillin was more active than tetracycline against this organism. These observations, together with the demonstration of a powerful bactericidal activity of ampicillin against Bacterium coli and Staphylococcus aureus in a concentration only five to 10 times the bacteriostatic level (Rolinson and Stevens, 1961), suggested that this antibiotic might be able to kill $H$. influenzae in the bronchial tree, rather than merely to inhibit it, as does tetracycline.

Several investigators have in fact reported encouraging results of trials of ampicillin in $H$. influenzae respiratory infections (Ayliffe and Pride, 1962 ; Grant, Douglas, and Murray, 1962 ;
Lockey, Eaton, and Compston, 1962 ; Trafford, Maclaren, Lillicrap, Barnes, Houston, and Knox, 1962 ; Millard and Batten, 1963), but none mentions the progress of the patients after therapy was stopped. This seems to us to be an important omission, since we believe that a new antibiotic can contribute significantly to progress in this field only if a relapse of infection does not occur rapidly after treatment. It is to this aspect, therefore, that we have given most attention in the investigation reported here.

\section{MATERIAL AND METHODS}

GENERAL PLAN OF INVESTIGation An indication of the likely efficacy of different dosage schedules was obtained by measuring the concentration of ampicillin attained in the sputum after different doses, and comparing these with the sensitivity of $H$. influenzae to the antibiotic in vitro. Practical clinical tests were then carried out. These involved the following procedures: (1) Initial examination of the patient's sputum; (2) administration of the appropriate dose of ampicillin $\exists$ for a fixed period (one or two weeks) ; and (3) observation of the patient after therapy in order to determine if and when relapse occurred.

Although regular enquiries were naturally made into the patient's subjective feelings, assessments of progress were made entirely objectively by examination of the sputum (see below).

Patients Twenty-nine patients were studied, 20 men and 9 women. All were chronic bronchitics attending Brompton Hospital, and their ages ranged from 30 to 75 years. In no instance was there clinical evidence of gross bronchiectasis, but bronchography was not routinely carried out. All were in-patients throughout the period of administration of ampicillin and for varying times thereafter. $H$. influenzae was isolated from the sputum of each of them before treatment, except where specifically mentioned.

While patients were in hospital their sputa were examined every day except Saturday and Sunday. At each 'examination' the purulence and quantity of the sputum expectorated in the preceding 24 hours were 
noted and cultures were made of the first three specimens produced in the morning.

Purulence was assessed by naked-eye inspection. The following grades were recognized:

$$
\begin{aligned}
& \text { Mucopurulent } \\
& \text { (MP) } t++ \text { approximately } 75 \% \text { pus or more } \\
& \text { MP }++ \text { approximately } 50 \% \text { pus or more } \\
& \mathrm{MP}+\quad \text { approximately } 25 \% \text { pus or more } \\
& \mathrm{MP} \pm \\
& \text { Mucoid (M) } \\
& \text { trace of pus } \\
& \text { no pus }
\end{aligned}
$$

Naturally these gradings were very approximate, but they provided a much more accurate and useful description of the sputum than does the term 'mucopurulent' without qualification.

In order to obviate observer error as far as possible, sputum samples were inspected by both authors before an agreed grading was noted.

The quantity of sputum expectorated was measured by weighing it and was expressed in grams. This is the standard method of assessment of sputum output used at the Brompton Hospital.

Cultures of sputum were made on blood agar after preliminary homogenization with pancreatin (Rawlins, 1953). $H$. influenzae was identified by appropriate diagnostic tests.

OUT-PATIENT PROCEDURE When the patients left hospital it was necessary that between out-patient visits they should make their own daily records of sputum volume and character. Naturally this introduced a large and indefinable observer variation between patients, but we have found in former investigations that most bronchitic patients need little encouragement to become 'sputum-minded' and can be trained to make useful observations. While they were in hospital, therefore, they were instructed in the recognition of pus in the sputum and shown how to measure the amount expectorated by means of a $1 \mathrm{oz}$. glass jar supplied for the purpose. The final interpretation of the patient's description was made at each out-patient attendance by comparison with the appearance of three fresh samples expectorated on that day. Each of these samples was cultured.

Although the out-patient procedure was naturally unsatisfactory in comparison with the procedure in hospital, we feel nevertheless that the method adopted was the best possible compromise. The retention of patients in hospital throughout the period of observation would have been ideal but was impracticable for numerous reasons.

ESTIMATION OF AMPICILLIN IN SPUTUM The procedure was the same as that used by May (1955) for estimating penicillin concentration in the sputum.

(1) Specimens of sputum were obtained immediately before and at set times after the administration of ampicillin.

(2) Each specimen was liquefied by the addition of a measured volume (approximately equal to the volume of sputum) of $1 \%$ pancreatin solution and incubation at $37^{\circ} \mathrm{C}$. for about one hour. The total volume of the liquefied sputum was measured, and, knowing the volume of pancreatin used, the original volume of the sputum and its dilution were calculated. Further dilution with physiological saline, in order to adjust the ampicillin concentration to a convenient level for estimation, was sometimes made in the light of previous experience of the concentrations likely to be found.

(3) The concentration of ampicillin in the diluted liquefied sputum was determined by the cylinder-plate method using a highly sensitive strain of Sarcina lutea (W.H.O. strain PCI/1001) as the test organism. Duplicate samples of each sputum, together with control solutions of ampicillin, $0 \cdot 1,0.05$, and $0.025 \mu \mathrm{g} . / \mathrm{ml}$., were tested on each plate. For each batch of tests a curve was plotted of the means of the diameters of the inhibition zones produced by all the control solutions of each strength. The concentration of ampicillin in each sputum specimen was determined by reference to this curve of the mean of the diameters of the inhibition zones of the two samples. The result so obtained was multiplied by the dilution of the sputum.

ESTIMATION OF THE SENSITIVITY OF $H$. influenzae to ANTIBIOTICS The minimal inhibitory concentrations of antibiotics for $\boldsymbol{H}$. influenzae were estimated by titration on agar containing haemin and yeast extract ( $\mathrm{X}$ and $\mathrm{V}$ growth factors for $H$. influenzae) in petri dishes. Suspensions of the organism were 'spotted' on to a series of six plates containing $5,2 \cdot 5,1 \cdot 25,0.6,0.3$, and $0.15 \mu \mathrm{g} . / \mathrm{ml}$. respectively of the test antibiotic, and also on a control plate containing no antibiotic. During the present investigation ampicillin was the only antibiotic to which sensitivity was tested; the figures quoted for sensitivity to penicillin $G$ and tetracycline were obtained by the same technique used for routine purposes during the last three years.

The bactericidal activity of ampicillin was estimated as follows. A series of solutions, 5, 2.5, 1.25, 0.6, 0.3, and $0.15 \mu \mathrm{g} . / \mathrm{ml}$., was prepared in $0.5 \mathrm{ml}$. quantities of nutrient broth containing $X$ and $V$ factors, and each was inoculated with a drop from a suspension of the test strain of $H$. influenzae; the final inoculum was approximately $50 \times 10^{6}$ organisms $/ \mathrm{ml}$. After overnight incubation at $37^{\circ} \mathrm{C}$. the minimal inhibitory concentration was noted and subcultures were made from each tube in order to determine the presence or absence of viable organisms. The minimal bactericidal concentration was recorded as the lowest concentration from which no living organisms could be isolated.

\section{RESULTS}

Table I shows the minimal inhibitory concentrations of ampicillin for 36 strains of $H$. influenzae in vitro. For comparison are shown the sensitivities of 174 strains to penicillin $G$ and 161 strains to tetracycline. The greater activity of 
T ABLE I

SENSITIVITY OF H. INFLUENZAE TO AMPICILLIN, PENICILLIN G, AND TETRACYCIINE

\begin{tabular}{|c|c|c|c|c|c|c|c|}
\hline \multirow{2}{*}{ Antibiotic } & \multirow{2}{*}{$\begin{array}{l}\text { Total No. of } \\
\text { Strains } \\
\text { Tested }\end{array}$} & \multicolumn{6}{|c|}{ No. of Strains Inhibited by ( $\mu \mathrm{g} . \mathrm{ml})}$. \\
\hline & & 5 & $2 \cdot 5$ & $1 \cdot 25$ & 0.6 & $0 \cdot 3$ & $0 \cdot 15$ \\
\hline Ampicillin & 36 & $36(100)$ & $36(100)$ & $36(100)$ & $36(100)$ & $14(66)$ & $9(25)$ \\
\hline Penicillin G & 174 & $173(100)$ & $171(98)$ & $150(86)$ & $71(41)$ & $15(9)$ & $4(2)$ \\
\hline Tetracycline & 161 & $161(100)$ & $144(90)$ & $81(50)$ & $24(15)$ & $6(4)$ & $2(1)$ \\
\hline
\end{tabular}

Figures in parentheses are percentages.

ampicillin compared with that of the other two antibiotics is of the same order as that reported in smaller series by Rolinson and Stevens (1961) and Stewart et al. (1961). It will be noted that all strains tested were inhibited by $0.6 \mu \mathrm{g} . / \mathrm{ml}$.; twothirds by $0.3 \mu \mathrm{g} . / \mathrm{ml}$.; and one-quarter by $0.15 \mu \mathrm{g} . / \mathrm{ml}$.

Minimal bactericidal concentrations were estimated for six strains of $H$. influenzae. In four instances they were respectively four times, twice, twice, and eight times the corresponding minimal inhibitory concentrations. The remaining two strains, however, were different in that no viable organisms could be recovered after 24 hours from tubes which showed macroscopic growth. It seemed that these strains were rapidly killed after initial multiplication.

AMPICILLIN CONCENTRATIONS IN SPUTUM The two dosage regimes investigated most thoroughly were $250 \mathrm{mg}$. six-hourly and $500 \mathrm{mg}$. six-hourly. In addition, two patients receiving $500 \mathrm{mg}$. eighthourly were studied, but the findings were of limited value, since one patient's sputum showed abnormally high levels whereas the other apparently did not take his ampicillin as instructed.

The Figure shows curves of the ampicillin concentrations attained in the sputa of two patients receiving $250 \mathrm{mg}$. and $500 \mathrm{mg}$. respectively every six hours. These are representative of the findings for the two regimes. In Table II are given the figures for all the patients studied. Various points require comment.

First, each estimation was made six hours after a dose of ampicillin during a six-hourly dosage schedule. We have not studied levels at other times in detail, but such observations as we have made indicate that the maximum concentration is reached about three to four hours after administration. The level at that time does not greatly exceed that at six hours, but even so the figures given in Table II represent concentrations less than the maximum.

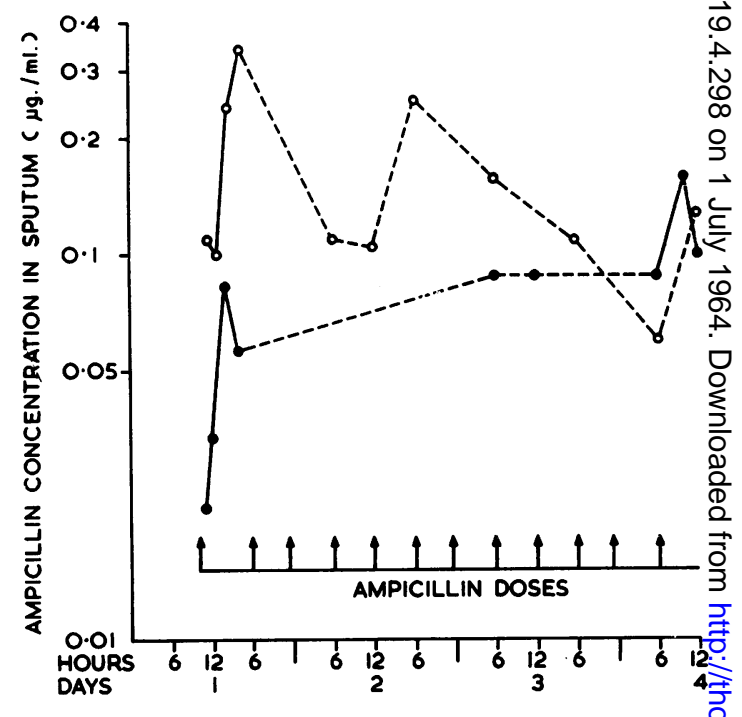

FIGURE. Curves showing the concentrations of ampicillio found in the sputa of two patients receiving $250 \mathrm{mg}$. (lower curve) and $500 \mathrm{mg}$. (upper curve) every six hours Where the lines are interrupted, peak levels were not estimated between doses.

TABLE II

CONCENTRATION OF AMPICILLIN IN SPUTUM SIX HOUR AFTER A DOSE

\begin{tabular}{|c|c|c|c|c|}
\hline \multirow{2}{*}{$\begin{array}{c}\text { Patient } \\
\text { No. }\end{array}$} & \multirow{2}{*}{$\begin{array}{l}\text { Dose } \\
\text { (mg.) }\end{array}$} & \multirow{2}{*}{$\begin{array}{l}\text { No. of } \\
\text { Observa- } \\
\text { tions }\end{array}$} & \multicolumn{2}{|c|}{$\begin{array}{l}\text { Ampicillin Concentration in } \\
\text { Sputum }(\mu \mathrm{g} . / \mathrm{ml} .)\end{array}$} \\
\hline & & & Range & Mean \\
\hline $\begin{array}{l}1 \\
2 \\
3 \\
4 \\
5\end{array}$ & $\begin{array}{l}250 \\
250 \\
250 \\
250 \\
250\end{array}$ & $\begin{array}{l}5 \\
6 \\
6 \\
3 \\
2\end{array}$ & $\begin{array}{l}0.05-0.1 \\
0.03-0.2 \\
0.04-0.11 \\
0.02-0.04 \\
0.07-0.09\end{array}$ & $\begin{array}{l}0.08 \\
0.12 \\
0.07 \\
0.03 \\
0.08\end{array}$ \\
\hline Total & & 22 & $0.02-0.2$ & 0.08 \\
\hline $\begin{array}{l}3 \\
4 \\
5 \\
6 \\
7 \\
8 \\
9\end{array}$ & $\begin{array}{l}500 \\
500 \\
500 \\
500 \\
500 \\
500 \\
500\end{array}$ & $\begin{array}{r}7 \\
5 \\
7 \\
13 \\
7 \\
11 \\
14\end{array}$ & $\begin{array}{l}0.06-0.25 \\
0.06-0.22 \\
0.07-0.25 \\
0.02-0.25 \\
0.06-0.38 \\
0.16-0.85 \\
0.12-0.53\end{array}$ & $\begin{array}{l}0.13 \\
0.15 \\
0.13 \\
0 \cdot 13 \\
0 \cdot 2 \\
0.51 \\
0 \cdot 29\end{array}$ \\
\hline \multicolumn{2}{|c|}{$\begin{array}{l}\text { Total } \\
\text { Total excluding } \\
\text { patient No. } 8\end{array}$} & $\begin{array}{l}64 \\
53\end{array}$ & $\begin{array}{l}0.02-0.85 \\
0.02-0.53\end{array}$ & $\begin{array}{l}0 \cdot 24 \\
0 \cdot 18\end{array}$ \\
\hline
\end{tabular}


Secondly, it will be noted that some patients showed a wide range of concentrations from one specimen to another. The figures, however, are slightly misleading in that they indicate merely the highest and lowest finding for each patient; they do not show the general trend of the estimations as a whole. For example, patient 3 , when receiving $500 \mathrm{mg}$. six-hourly, showed a range of from 0.06 to $0.25 \mu \mathrm{g} . / \mathrm{ml}$. in his sputum. The figures for all the seven observations made, however, were $0.11,0.1,0.25,0.16,0.11,0.06$, and 0.13 , a remarkably consistent series. In contrast, some patients showed a much greater scatter, as for example patient 6 , in whom the concentrations found were $0.11,0.23,0.18,0.10,0.25,0.09,0.02$, $0.08,0.02,0.19$, and 0.22 . How far the variations reflect true fluctuations in the ampicillin concentration and how far they are due to experimental error is not known. Sputum is unsatisfactory material in which to estimate antibiotic concentration because of the unknown and uncontrollable degree of contamination with saliva.

This undoubtedly contributes to the experimental error and may well account for a large part of the variation between specimens. Clearly it is necessary, in any given patient, to estimate the concentration of antibiotics in several specimens of sputum before coming to a conclusion as to the true level.

Thirdly, whatever the degree of variation between specimens in individual patients, there is nevertheless a considerable consistency between the mean levels obtained in different subjects. Occasionally, however, one patient differs strikingly from the rest. One example has been mentioned above in connexion with a dosage regime of $500 \mathrm{mg}$. eight-hourly. Another is patient 8 in Table II. Consistently high concentrations were found in this patient's sputum; on one occasion a level of $0.85 \mu \mathrm{g} . / \mathrm{ml}$. was reached.

Bearing these points in mind, one may conclude that the sputum concentration obtainable during the administration of $250 \mathrm{mg}$. of ampicillin sixhourly is likely to be of the order of $0.1 \mu \mathrm{g} . / \mathrm{ml}$., while on a dosage of $500 \mathrm{mg}$. six-hourly it is likely to be about $0.2 \mu \mathrm{g} . / \mathrm{ml}$.

THEORETICAL DOSAGE CONSIDERATIONS The thesis that the sputum concentration of an antibiotic provides a better index than the blood concentration to the likely response to chemotherapy has been discussed elsewhere (May, 1955). On this

TABLE III

RESPONSE OF PATIENTS' SPUTUM TO 500 MG. AMPICILLIN SIX-HOURLY

\begin{tabular}{|c|c|c|c|c|c|c|c|c|c|c|c|c|c|c|c|c|}
\hline \multirow{2}{*}{$\begin{array}{c}\text { Patient } \\
\text { No. }\end{array}$} & \multirow{2}{*}{ Sputum } & \multicolumn{14}{|c|}{ Ampicillin Administration (days) } & \multirow{2}{*}{$\begin{array}{l}\text { Time of } \\
\text { Relapse }\end{array}$} \\
\hline & & 1 & 2 & 3 & 4 & 5 & 6 & 7 & 8 & 9 & 10 & 11 & 12 & 13 & 14 & \\
\hline 4 & $\begin{array}{l}\text { Quantity (g.) } \\
\text { Pus } \\
\text { H.influenzae }\end{array}$ & $\begin{array}{c}15 \\
++t \\
++\end{array}$ & $\begin{array}{c}10 \\
++\end{array}$ & $\begin{array}{l}\operatorname{tr} \\
+\end{array}$ & 30 & 15 & 15 & 15 & & & & & & & & $\begin{array}{c}\text { No } \\
\text { observation }\end{array}$ \\
\hline 5 & $\begin{array}{l}\text { Quantity (g.) } \\
\text { Pus } \\
\text { H.influenzae }\end{array}$ & $\begin{array}{c}75 \\
++ \\
+++\end{array}$ & $\begin{array}{c}50 \\
++\end{array}$ & $\begin{array}{l}55 \\
\pm \\
-\end{array}$ & $\begin{array}{l}45 \\
- \\
-\end{array}$ & 35 & 20 & 45 & & & & & & & & $\begin{array}{c}\text { No } \\
\text { observation }\end{array}$ \\
\hline 6 & $\begin{array}{l}\text { Quantity (g.) } \\
\text { Pus } \\
\text { H.influenzae }\end{array}$ & $\begin{array}{c}110 \\
++ \\
+\end{array}$ & $\begin{array}{l}80 \\
\pm \\
-\end{array}$ & $\begin{array}{l}50 \\
- \\
-\end{array}$ & $\begin{array}{l}50 \\
- \\
-\end{array}$ & $\begin{array}{l}80 \\
- \\
-\end{array}$ & $\begin{array}{l}60 \\
- \\
-\end{array}$ & $\begin{array}{l}80 \\
- \\
-\end{array}$ & & & & & & & & $\begin{array}{c}\text { No } \\
\text { observation }\end{array}$ \\
\hline 7 & $\begin{array}{l}\text { Quantity (g.) } \\
\text { Pus } \\
\text { H.influenzae }\end{array}$ & $\begin{array}{c}25 \\
+\begin{array}{c}+ \\
\pm\end{array}\end{array}$ & $\begin{array}{c}15 \\
++ \\
\pm\end{array}$ & $\begin{array}{l}20 \\
+ \\
\pm\end{array}$ & $\begin{array}{l}20 \\
\pm \\
\pm\end{array}$ & 20 & $\underline{\operatorname{tr}}$ & $\frac{\operatorname{tr}}{-}$ & & & & & & & & $\begin{array}{l}6 \text { months } \\
6 \text { months }\end{array}$ \\
\hline 19 & $\begin{array}{l}\text { Quantity (g.) } \\
\text { Pus } \\
\text { H.influenzae }\end{array}$ & $\begin{array}{c}45 \\
++ \\
+\end{array}$ & $\begin{array}{l}75 \\
+ \\
-\end{array}$ & $\begin{array}{c}70 \\
++ \\
+\end{array}$ & $\begin{array}{c}40 \\
++ \\
-\end{array}$ & 20 & 40 & $\begin{array}{c}75 \\
++ \\
+\end{array}$ & & & & & & & & $\begin{array}{l}\text { Never cleared } \\
\text { Never cleared }\end{array}$ \\
\hline 20 & $\begin{array}{l}\text { Quantity (g.) } \\
\text { Pus } \\
\text { H.influenzae }\end{array}$ & $\begin{array}{c}20 \\
+++ \\
\pm\end{array}$ & $\begin{array}{c}15 \\
+++ \\
++t\end{array}$ & 15 & 20 & 15 & $\begin{array}{c}15 \\
+ \\
++\end{array}$ & $\begin{array}{r}5 \\
\pm \\
++ \\
\end{array}$ & & & & & & & & $\begin{array}{l}++ \text { after } 17 \\
\text { days } \\
\text { Never cleared }\end{array}$ \\
\hline 21 & $\begin{array}{l}\text { Quantity (g.) } \\
\text { Pus } \\
\text { H.influenzae }\end{array}$ & $\begin{array}{c}35 \\
++ \\
++\end{array}$ & $\begin{array}{c}20 \\
++ \\
+\end{array}$ & 20 & 15 & $\begin{array}{l}15 \\
\pm \\
\pm\end{array}$ & $\begin{array}{l}15 \\
\pm\end{array}$ & $\begin{array}{l}15 \\
-\end{array}$ & $\begin{array}{l}20 \\
\overline{ \pm} \\
\end{array}$ & & & & $\begin{array}{l}- \\
-\end{array}$ & $\begin{array}{l}25 \\
-\end{array}$ & 25 & 14 days \\
\hline 22 & $\begin{array}{l}\text { Quantity (g.) } \\
\text { Pus } \\
\text { H.influenzae }\end{array}$ & $\begin{array}{c}55 \\
++ \\
++\end{array}$ & 70 & 40 & $\begin{array}{c}35 \\
+++ \\
-\end{array}$ & $\begin{array}{c}35 \\
+++ \\
-\end{array}$ & $+\frac{t}{-}$ & $\begin{array}{c}25 \\
++ \\
-\end{array}$ & $\begin{array}{c}35 \\
++\end{array}$ & 30 & 30 & 15 & $\begin{array}{l}10 \\
\pm\end{array}$ & $\begin{array}{l}\frac{15}{ \pm} \\
\end{array}$ & $\begin{array}{l}10 \\
-\end{array}$ & $\begin{array}{l}3 \text { days } \\
3 \text { days }\end{array}$ \\
\hline 23 & $\begin{array}{l}\text { Quantity (g.) } \\
\text { Pus } \\
\text { H.influenzae }\end{array}$ & $\begin{array}{l}45 \\
+ \\
+\end{array}$ & $\begin{array}{l}40 \\
- \\
-\end{array}$ & $\begin{array}{l}60 \\
- \\
-\end{array}$ & $\begin{array}{l}45 \\
-\end{array}$ & $\begin{array}{l}45 \\
-\end{array}$ & $\frac{75}{ \pm}$ & $\begin{array}{l}70 \\
-\end{array}$ & $\begin{array}{l}30 \\
-\end{array}$ & 90 & 50 & 30 & $\begin{array}{l}90 \\
- \\
-\end{array}$ & $\begin{array}{l}75 \\
\pm\end{array}$ & $\begin{array}{l}15 \\
-\end{array}$ & $\begin{array}{r}18 \text { days } \\
4 \text { days }\end{array}$ \\
\hline
\end{tabular}


basis the figures in Tables I and II suggest that less than one quarter of $H$. influenzae infections can be expected to respond to $250 \mathrm{mg}$. six-hourly and only about one half to double this dose.

Since the sensitivity of $H$. influenzae quoted in Table I refers to the bacteriostatic activity of ampicillin, and since the bactericidal concentration is likely to be up to eight times greater, it is probable that doses of the size mentioned will not in any instance kill $H$. influenzae in the sputum. Responses therefore are likely to be limited to temporary suppression while ampicillin is being administered, relapses occurring soon after it is stopped.

In view of the unpromising preliminary findings given above, attention was initially directed mainly towards daily doses of $2 \mathrm{~g}$. (500 mg. sixhourly), although, in view of the uncertainty about the influence of the peak sputum levels some investigations of a smaller dose, namely $1 \frac{1}{2} \mathrm{~g}$. (500 mg. eight-hourly), were carried out. Later investigations with a much bigger dose, $4 \mathrm{~g}$. daily, are described separately below.

ELIMINATION OF PUS AND $\boldsymbol{H}$. influenzae FROM THE SPUTUM Tables III and IV show the changes that occurred in patients' sputa during the administration of $500 \mathrm{mg}$. of ampicillin six- and eight-hourly respectively. The disappearance of pus from some patients was dramatic, e.g., patients $4,5,6, \underset{\overrightarrow{\overrightarrow{0}}}{\stackrel{\vec{\rho}}{+}}$ and 12 , but in others it diminished much more slowly, e.g., patients $20,22,13$, and 17 ; in some 흠 it was still present in significant amounts at the $\frac{\bar{m}}{7}$

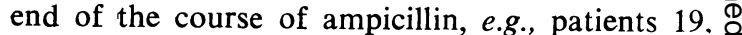
11 , and 14 .

The elimination of $\boldsymbol{H}$. influenzae was as unpredictable as was the elimination of pus. As a rule, isolation of this organism became $\vec{\omega}$ increasingly difficult while ampicillin was being administered, but in several patients it was still $\vec{x}$ found at the end of the course, e.g., patients $19, \stackrel{\vec{\varphi}}{\vec{\varphi}}$ $20,12,13$, and 14 ; sometimes it was present in 6 numbers as large as before treatment, e.g., i patient 20 .

No useful purpose is served by attempting to 을 analyse in detail the findings in this small series. The results showed that the response to $\subsetneq$ ampicillin in dosage regimes of the order shown $₹$ in the tables is more or less as might be expected $\vec{\theta}$ from the sputum levels investigated earlier. An $\stackrel{\varnothing}{\perp}$ important point not shown, however, is that several of the patients had previously received tetracycline with variable degrees of benefit. In some instances, e.g., patients $4,5,6$, and 7 , tetracycline was quite unable to control the infection $\frac{0}{\varnothing}$ but ampicillin caused a dramatic improvement.

The quantity of sputum expectorated daily was $\overrightarrow{\overrightarrow{0}}$ often reduced during ampicillin treatment (Tables III and IV). The significance of this must be

TABLE IV

RESPONSE OF PATIENTS' SPUTUM TO 500 MG. AMPICILLIN EIGHT-HOURLY

\begin{tabular}{|c|c|c|c|c|c|c|c|c|c|c|c|c|c|c|c|c|}
\hline \multirow{2}{*}{$\begin{array}{l}\text { Patient } \\
\text { No. }\end{array}$} & \multirow{2}{*}{ Sputum } & \multicolumn{14}{|c|}{ Ampicillin Administration (days) } & \multirow{2}{*}{$\begin{array}{l}\text { Time of } \\
\text { Relapse }\end{array}$} \\
\hline & & 1 & 2 & 3 & 4 & 5 & 6 & 7 & 8 & 9 & 10 & 11 & 12 & 13 & 14 & \\
\hline 11 & $\begin{array}{l}\text { Quantity (g.) } \\
\text { Pus } \\
\text { H. influenzae }\end{array}$ & $\begin{array}{c}50 \\
+++ \\
+++\end{array}$ & $\begin{array}{c}65 \\
+++\end{array}$ & $\begin{array}{c}25 \\
+\end{array}$ & 30 & $\begin{array}{l}35 \\
\pm\end{array}$ & $\begin{array}{r}25 \\
+ \\
- \\
\end{array}$ & $\begin{array}{l}15 \\
+ \\
-\end{array}$ & & & & & & & & No observation \\
\hline 12 & $\begin{array}{l}\text { Quantity (g.) } \\
\text { Pus } \\
H . \text { influenzae }\end{array}$ & $\begin{array}{l}60 \\
++ \\
++ \\
\end{array}$ & 65 & 25 & $\begin{array}{l}30 \\
\pm \\
+ \\
+\end{array}$ & $\begin{array}{l}20 \\
\stackrel{\square}{ \pm} \\
\end{array}$ & $\begin{array}{l}15 \\
\pm \\
\pm\end{array}$ & $\begin{array}{l}15 \\
\pm \\
\pm\end{array}$ & & & & & & & & $\begin{array}{l}5 \text { days } \\
\text { Never cleared }\end{array}$ \\
\hline 13 & $\begin{array}{l}\text { Quantity (g.) } \\
\text { Pus } \\
\text { H.influenzae }\end{array}$ & $\begin{array}{r}60 \\
++ \\
++ \\
\end{array}$ & $\begin{array}{c}40 \\
++ \\
+\end{array}$ & $\begin{array}{c}120 \\
+ \\
\pm\end{array}$ & 30 & 20 & $\begin{array}{l}15 \\
\pm \\
\pm \\
\end{array}$ & $\begin{array}{l}60 \\
- \\
+ \\
\end{array}$ & & & & & & & & $\begin{array}{l}9 \text { days } \\
\text { Never cleared }\end{array}$ \\
\hline 14 & $\begin{array}{l}\text { Quantity (g.) } \\
\text { Pus } \\
H . \text { influenzae }\end{array}$ & $\begin{array}{c}++ \\
+\end{array}$ & ++ & $+t$ & ++ & ++ & $+t$ & $\begin{array}{c}++ \\
+ \\
\end{array}$ & & & & & & & & $\begin{array}{l}\text { Never cleared } \\
\text { Never cleared }\end{array}$ \\
\hline 16 & $\begin{array}{l}\text { Quantity (g.) } \\
\text { Pus } \\
\text { H. influenzae }\end{array}$ & $\begin{array}{l}10 \\
\pm\end{array}$ & 10 & $\frac{15}{-}$ & $\begin{array}{l}45 \\
\pm \\
\pm\end{array}$ & $\begin{array}{l}20 \\
- \\
-\end{array}$ & $\begin{array}{l}\operatorname{tr} \\
- \\
\end{array}$ & 20 & 10 & $\underline{\operatorname{tr}}$ & $\begin{array}{l}40 \\
- \\
-\end{array}$ & $\begin{array}{c}25 \\
- \\
- \\
\end{array}$ & 20 & 20 & 20 & $\begin{array}{l}\text { None at any } \\
\text { time } \\
4 \text { days }\end{array}$ \\
\hline 17 & $\begin{array}{l}\text { Quantity (g.) } \\
\text { Pus } \\
\text { H. influenzae }\end{array}$ & $\begin{array}{c}60 \\
++ \\
\pm\end{array}$ & $\begin{array}{c}40 \\
++\end{array}$ & 30 & 30 & $\begin{array}{l}45 \\
\pm \\
\pm\end{array}$ & $\begin{array}{l}45 \\
+ \\
\pm\end{array}$ & $\begin{array}{l}45 \\
+ \\
\pm\end{array}$ & $\begin{array}{c}20 \\
+\end{array}$ & 40 & 35 & $\begin{array}{l}30 \\
\pm \\
\end{array}$ & $\begin{array}{l}50 \\
\pm \\
\pm\end{array}$ & $\begin{array}{l}30 \\
\pm \\
\pm \\
\end{array}$ & $\begin{array}{l}45 \\
\pm \\
-\end{array}$ & $\begin{array}{l}17 \text { days } \\
\text { Not cultured }\end{array}$ \\
\hline 18 & $\begin{array}{l}\text { Quantity (g.) } \\
\text { Pus } \\
\text { H.influenzae }\end{array}$ & 40 & $\begin{array}{r}25 \\
+ \\
++\end{array}$ & $\frac{15}{ \pm}$ & $\begin{array}{l}15 \\
-\end{array}$ & $\begin{array}{l}15 \\
-\end{array}$ & $\begin{array}{l}20 \\
- \\
-\end{array}$ & $\begin{array}{l}25 \\
- \\
-\end{array}$ & $\begin{array}{l}15 \\
-\end{array}$ & $\begin{array}{l}15 \\
-\end{array}$ & $\begin{array}{l}10 \\
-\end{array}$ & $\begin{array}{l}10 \\
- \\
-\end{array}$ & 15 & 20 & $\begin{array}{c}25 \\
-\end{array}$ & 14 days \\
\hline
\end{tabular}

Numbers $7,8,12,17,19,20,21,22$ and 27 were women and the rest were men. 
assessed with caution, however, since many of the patients were also carrying out postural drainage, which may also have influenced the volume of sputum.

RELAPSES OF INFECTION AFTER AMPICILLIN THERAPY Tables III and IV also show the lengths of time after the end of ampicillin administration during which the patients' sputa remained free from pus and $\boldsymbol{H}$. influenzae. With the exception of patient 7, 18 days was the longest period of freedom from pus. Reappearance of $\boldsymbol{H}$. influenzae usually occurred much more quickly. In no instance was the strain isolated during the relapse found to be more resistant to ampicillin than that isolated before treatment.

Patient 7, a woman aged 37 years, was exceptional. She suffered from severe asthma and bronchitis of many years' duration and persistently expectorated thick purulent sputum which was uninfluenced by tetracycline. During a week's treatment with ampicillin there was a dramatic disappearance of the pus, followed by cessation of all expectoration for six months. No other factor could be held to account for this response, which seemed to be associated with a true bactericidal effect of ampicillin against the infecting organism. In this connexion it is perhaps worth noting that the ampicillin concentration in this patient's sputum was around $0.2 \mu \mathrm{g} . / \mathrm{ml}$. (Table II), whereas the sensitivity (bacteriostatic) of her strain of $H$. influenzae was $0.1 \mu \mathrm{g} . / \mathrm{ml}$. The bactericidal concentration of ampicillin for this strain is not known.

As stated earlier, a correlation of ampicillin levels in the sputum with the sensitivity of $H$. influenzae in vitro suggested that doses of ampicillin of $2 \mathrm{~g}$. or less daily were unlikely to cause responses substantially different from those obtainable with tetracycline; and this prediction proved to be correct. However, whereas the bactericidal concentration of tetracycline is too high to be attainable in the sputum with any practical dosage system, that of ampicillin is low enough to be theoretically within grasp. Unfortunately, ampicillin is an expensive drug, and the excessive cost of a regime involving a high dosage would need to be offset by making the course a short one. Further, it would be desirable that repetition of the course should not be required for several weeks at least. Bearing these points in mind, a regime of $1 \mathrm{~g}$. ampicillin sixhourly for one week was investigated.

Six patients have so far been treated in this way. Each had persistently purulent sputum and normally relied upon continuous antibiotictherapy to control the infection during the winter. $H$. influenzae was isolated from the sputum of four of them before treatment. Cultures from the fifth were persistently overgrown by Proteus, while no pathogens could be found in the sixth, a man who had taken tetracycline for a long period immediately preceding the ampicillin treatment. The week's course of ampicillin was given in each instance between the beginning of November 1962 and the middle of January 1963. Pus was cleared from the sputum in every case, as was $H$. influenzae from those patients in whom it had been found. The quantity of sputum expectorated was also convincingly reduced. No side effects were noted.

The experience of the patients with regard to relapses was as follows. One remained free from infection for 12 weeks; he was then readmitted to hospital with a pulmonary embolism and given prophylactic tetracycline although his sputum remained mucoid. Another remained free from infection for four months, when an acute exacerbation of bronchitis supervened; and two others were still free when last seen three and two months respectively after treatment. The follow-up history of the fifth patient was rather difficult to assess, since on three occasions within the two months after treatment he was given antibiotics (tetracycline once, ampicillin twice) by his doctor for 'colds'. Careful inquiry suggested that on no occasion did pus reappear in the sputum, but it is possible that it might have done so if antibiotics had been withheld. When last seen five months after treatment, this patient's sputum was still mucoid and he emphatically claimed that he had had 'the best winter for years'.

The sixth patient unfortunately developed pneumococcal pneumonia only seven days after his course of ampicillin, and $\boldsymbol{H}$. influenzae was isolated from his sputum at the same time. The pneumococcus causing this infection must have been of exogenous origin, and it is possible that the haemophilus was acquired at the same time. At any rate the sputum again became frankly purulent shortly after the pneumonia had been cured by penicillin $G$, but whether this represented a true relapse of the original infection or an exogenous re-infection cannot be determined.

In only one patient was the estimation of ampicillin levels in the sputum possible ; concentrations of 0.22 and $0.08 \mu \mathrm{g} . / \mathrm{ml}$. were found in the two samples examined. These levels are lower than expected, but they provide insufficient evidence upon which to base reliable conclusions. Further investigations are clearly 
required and plans for a more detailed study are in hand.

\section{DISCUSSION}

The main therapeutic problem posed by chronic infections of the respiratory tract is the prevention of relapse when treatment is stopped. The advent of ampicillin brought the hope that this difficulty might be overcome, but the experience reported in this paper indicates that, in doses of the same order as those used for other antibiotics, this hope has not been realized. Our experience concerning the control of infection while the antibiotic is being administered is in accord with that of other investigators (Grant et al., 1962 ; Lockey et al., 1962 ; Millard and Batten, 1963), namely, that ampicillin, when given in doses of the order of 1 to $2 \mathrm{~g}$. daily, exerts approximately the same therapeutic effect as tetracycline. The possibility, however, that ampicillin may be effective in individual patients whose infections are uninfluenced by tetracycline, as we have frequently observed, gives this antibiotic a useful place in the treatment of these conditions. Further, we have formed the impression that response to ampicillin is often quicker than to tetracycline, and it is possible that, if the cost could be reduced, ampicillin might become the antibiotic of first choice.

The findings in the small preliminary investigation of a daily dose of $4 \mathrm{~g}$. are encouraging and indicate that a more extensive trial would be useful. Trafford et al. (1962) apparently used doses of this order with successful immediate results but insufficient detail is given in their report to assess the effect upon relapses of infection. In at least five of our six patients it seems that $\boldsymbol{H}$. influenzae was truly eradicated by a week's treatment with this dosage in contrast to the proportion of only one out of 16 patients treated with $1 \frac{1}{2}$ or $2 \mathrm{~g}$. daily. With tetracycline therapy such a result is even rarer in the type of patient taking part in this investigation, and it is probable therefore that ampicillin, if used in doses substantially higher than those now regarded as 'standard', would prove to be the more useful antibiotic.

The practicability of using ampicillin in this manner depends upon two inter-related factors: cost and duration of freedom from infection, i.e., the time lapse until another course of treatment is required. The more expensive the course, the longer the time lapse necessary if the over-all cost per annum is to compare favourably with that of continuous tetracycline. At the present time the cost of tetracycline, $1 \mathrm{~g}$. daily (the average $\stackrel{\overrightarrow{\vec{N}}}{\stackrel{\overrightarrow{0}}{+}}$ maintenance dose for a chronic bronchitic), is approximately $£ 212$ s. per week, whereas a week's $\frac{\bar{F}}{\overline{0}}$ treatment with ampicillin, $4 \mathrm{~g}$. daily, costs about $\frac{\rho}{\partial}$ $£ 12$ 10s. However, if this course of ampicillin were $\propto$ not to be repeated for say three months, the cost $\cong$ would be relatively small in comparison with that $\vec{O}$ of continuous tetracycline for the same period (approximately £34). Three months' freedom from $\vec{\omega}$ infection is an arbitrary length of time based on $\rho$ the observations reported in this paper. The actual $\vec{x}$ period in any given patient depends upon the $\overrightarrow{0}$ rapidity with which he acquires a new strain of $H$. influenzae from his contacts. This cannot be i controlled, but even if repetition of the ampicillin $\infty$ course were required as frequently as every five 의 weeks, its cost would still be no greater than that of continuous tetracycline therapy. In practice it $\subseteq$ is unlikely that the necessity for such frequent repetition would often arise.

It seems probable therefore that on economic $\stackrel{\Phi}{\oplus}$ as well as therapeutic grounds one-week courses of ampicillin, $4 \mathrm{~g}$. daily, would be acceptable, provided that the encouraging results reported here were confirmed in a larger trial. The cost of tetracycline mentioned above refers to patients $\frac{}{\varnothing}$ treated by general practitioners. In hospitals it is considerably less, but because of the customary음 restriction of information about the price of substances supplied under government contract, the exact cost cannot be made public. However, repetition of courses of ampicillin, $4 \mathrm{~g}$. daily, would have to be at intervals greatly in excess of the five weeks mentioned here for this method: of treatment to compete economically with continuous tetracycline therapy in hospital.

\section{SUMMARY}

The sensitivity of $\boldsymbol{H}$. influenzae to ampicillin in vitro has been compared with the concentration of the antibiotic attainable in the sputum. The $N$ result suggested that clinical responses to doses $N_{\omega}^{N}$ up to $2 \mathrm{~g}$. daily are unlikely to differ significantly from those obtainable with tetracycline. Thiso prediction has been confirmed by clinical $\frac{}{\Phi}$ observation.

A small preliminary investigation indicated that 0 a dose of $1 \mathrm{~g}$. six-hourly for one week may cause $\stackrel{P}{\vec{P}}$ complete eradication of $\boldsymbol{H}$. influenzae from the $\stackrel{\mathbb{D}}{\stackrel{D}{ }}$ sputum, with many subsequent weeks of freedom $\mathbb{\otimes}$ from infection. Such a response to other anti- $\frac{\Omega}{0}$ biotics is, in our experience, extremely rare in patients of the type taking part in this trial. 
The economic aspects of treatment with ampicillin in high dosage are discussed.

We wish to express our sincere thanks to Dr. J. C. Batten, Dr. J. R. Bignall, Dr. F. P. Lee Lander, and Dr. N. C. Oswald for allowing us to investigate their patients, and especially also to Dr. F. J. C. Millard for his unfailing co-operation in clinical matters; to Miss Beryl Godden and Mr. Charles Koch for technical assistance ; and to Beecham Research Laboratories Limited for a supply of ampicillin for use in this investigation.
REFERENCES

Ayliffe, G. A. J., and Pride, N. B. (1962). Brit. med. J., 2, 1641. Grant, I. W. B., Douglas, A. C., and Murray, W. D. (1962). Ibid., $2,482$.

Lockey, E., Eaton, B. R., and Compston, N.(1962). Brit.J. clin. Pract., 16, 13.

May, J. R. (1955). Brit. J. Tuberc., 49, 166. (1958). In Recent Trends in Chronic Bronchitis. Ed. Oswald, N. C. pp. 173-176. Lloyd-Luke, London.

Millard, F. J. C., and Batten, J. C. (1963). Brit. med. J., 1, 644.

Rawlins, G. A. (1953). Lancet, 2, 538.

Rolinson, G. N., and Stevens, S. (1961), Brit med. J., $2,191$.

Stewart, G. T., Coles, H. M. T., Nixon, H. H., and Holt, R. J. (1S61). Ibid., 2, 200.

Trafford, J. A. P., Maclaren, D. M., Lillicrap, D. A., Barnes, R. D. S., Houston, J. C., and Knox, R. (1962). Laricet, 1, 987. 